DOI: https://doi.org/10.31933/dijdbm.v2i6

Received: 30 September 2021, Revised: 20 October 2021, Publish: 29 October 2021

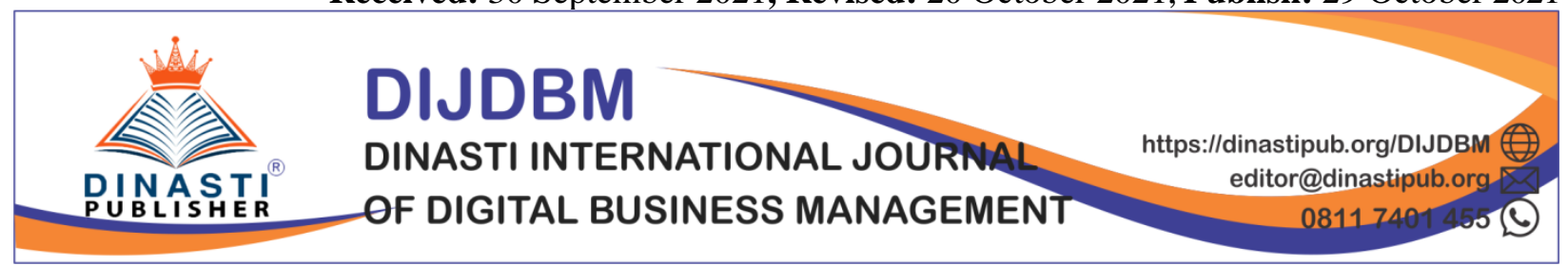

\title{
INFLUENCE OF PRODUCT QUALITY AND DESIGN ON THE PURCHASE DECISION OF HONDA CRV MOTOR VEHICLES AT PT. SINAR SENTOSA (CASE STUDY IN JAMBI CITY)
}

\section{Riko Mappedeceng ${ }^{1}$ \\ ${ }^{1)}$ Lecturer of the Faculty of Economics, Batanghari University, Jambi, Indonesia, rikomappedeceng@gmail.com}

\section{Corresponding Author: Riko Mappedeceng}

\begin{abstract}
This study aims to determine the effect of product quality and design on purchasing decisions on Honda CRV motor vehicles in Jambi City. The research methodology used is a quantitative method. The data used are secondary data and primary data. the population in this study were consumers of PT. SINAR SENTOSA who are consumers of CRV motorcycle users with a sample of 81 people. The analysis is regression test, $T$ test and $F$ test. The results of this study indicate that the application of product quality to consumers who have purchased a Honda CRV motor vehicle. product quality has a positive and significant effect on purchasing decisions for Honda CRV motor vehicles. expected PT. SINAR SENTOSA JAMBI will improve quality and design, in order to attract consumers to buy a Honda CRV motor vehicle.
\end{abstract}

Keywords: Product quality, Design Product, Buying decision

\section{INTRODUCTION}

The development of the automotive industry in Indonesia is progressing rapidly and rapidly. Currently, the automotive industry, such as motorcycle products, is currently experiencing a rapid increase and has become a lifestyle for the Indonesian people. Almost all people want a motorized vehicle to meet their daily needs, because it provides advantages such as fuel economy, the price is much cheaper, faster when the roads are congested, and the cost of spare parts is affordable.

The need for motorcycles has an impact on increasing demand for various types of motorcycles which results in more competition in the business world in the field of transportation, this can be seen from the many motorcycle manufacturers that offer various types of motorcycles with innovations with the need for which motorcycles are produced. provide 
many conveniences for consumers. One of the motorcycles on the market today and participating in the development of motorcycle technology is Honda. Honda is a Japanese manufacturer of cars, trucks, motorcycles and scooters. The Honda company also makes allterrain vehicles, electric generators and garden equipment. One of the motorcycle models that are in demand by the public and young people today is the Honda CRV.

The interest in choosing this brand is because Honda CRV motorcycle products are increasingly in demand, not only among Indonesian men but also among young people. Modern lifestyle is one of the individual factors that can influence a person's buying behavior. Honda CRV motorcycle is one of the dirt bikes or also called supermoto which was previously designed specifically for men, but is now in demand by all young people. Supermoto motorcycle models are getting faster. Its contribution is almost equivalent to sales of motorcycles with 150cc duck models and above, which are the mainstay products. Below, we will show the sales of Honda motorcycles and others.

Based on the table above, it can be seen that Honda CRV motorcycle sales in Jambi from 2016-2020 have increased every year, it can be seen that the average increase in motorcycle sales is $5.27 \%$ or in 2016 sold 318 units and in 2020 increased to as many as 411 units, this proves that Honda CRV motorcycles are in demand by the people in Jambi City. Based on the above phenomenon, the authors are interested in conducting research with the title: Effect of Product Quality and Design on Purchase Decisions for Honda CRV Motor Vehicles at PT. Sinar Sentosa Jambi (Case Study in Jambi City)

\section{LITERATURE REVIEW}

\section{Product quality}

According to Kotler (2010), a product is anything that can be offered to the market for attention, purchased, used, or consumed that can satisfy a want or need. Conceptually, the product is the subjective understanding of the producer on something that can be offered as an effort to achieve organizational goals through fulfilling the needs and activities of consumers, in accordance with the competence and capacity of the organization as well as the purchasing power of the market. Based on the above definition, the product is defined as a collection of tangible and intangible attributes, including packaging, color, price, quality and brand plus services and sales reputation. Product quality is something that needs the main attention of the company or producer considering that product quality is closely related to consumer decision problems (Sofjan Assauri, 2004). Product quality is related to the problem of customer satisfaction which is the goal of marketing activities carried out by the company. Product quality indicates a measure of the durability of the product, the trustworthiness of the product, easy to operate and maintain and other attributes that are valued by consumers

\section{Product design}


The problem of the design of a product has become one of the factors that need serious attention from management, especially the new product development team, because the intended target consumers are not a few who start to question the design problem of a product that is able to meet the needs and desires of consumers. This is the appearance and function of a product in meeting customer needs. Angipora (2002).

According to Kotler (2007) product design is a feature that affects the appearance and function of a product in terms of customer needs, a good product design can attract attention to make purchases, improve performance, reduce costs, and adjust value to the desired target market. Design is very important especially in manufacturing and marketing, packaged goods, and durable equipment. Design can be interpreted as a form that is a distinguishing characteristic of other products of the same type. Meanwhile, Armstrong (2004) stated that "Design is not just a thin appearance of the epidermis, the design goes into the heart of the product". Good design can contribute in terms of product usability as well as appearance. Product Design Indicators are characteristics that support the basic functions of the product, performance refers to the level of the main characteristics of the product when operating, quality of conformity is the level at which product design and operating characteristics are close to the target standard, Durability is a measure of the expected operating time of a particular product. Reliability is a measure of the probability that a product will not function incorrectly or damaged within a certain period of time, Repairability is a measure of the ease of repair. a product that malfunctions or damages, the model (Style) describes how far a product looks and is pleasing to consumers.

\section{Buying decision}

The consumer's decision to purchase a product is an action that is commonly taken by each individual consumer when making a buying decision. The decision to buy or not to buy is part of the element inherent in individual consumers called behavior which refers to real physical actions. Buchari Alma (2011: 96) argues that purchasing decisions as a consumer decision are influenced by the financial economy, technology, politics, culture, products, prices, locations, promotions, physical evidence, people and processes, thus forming an attitude for consumers to process all kinds of things. information and draw conclusions in the form of a response that appears what product to buy. According to Kotler and Keller translated by Tjiptono (2012: 193) the purchase decision is a decision stage where consumers actually make a purchase of a product.

According to Setiadi (2003:8) purchase decision is an integration process that combines knowledge to evaluate two or more alternative behaviors and choose one of them. According to Kotler and Keller (2008:166-189), indicators of purchasing decisions are needs, namely consumers recognize a problem or need, public is a decision-making stage where consumers are interested in seeking more information through mass media or customer appraisal organization, benefit is the stage of the purchasing decision process where consumers use information to evaluate the benefits, the attitude of others is the stage in the buying decision process where 
consumers get recommendations from others, Satisfaction is where consumers will take further action after buying based on satisfaction or dissatisfaction they feel in the Purchase Decision.

\section{RESEARCH METHOD}

In this study, researchers used a design using descriptive methods and quantitative methods (Sugiyono, 2014). Types and sources of data using primary data, namely by distributing questionnaires to consumers purchasing motor vehicles in Jambi City. Data collection techniques are by observing consumers who buy motor vehicles in the city of Jambi, this activity is carried out with the aim of observing and obtaining data and information on the activities to be studied. And Questionnaires by filling out a list of questions by distributing questionnaires to consumers so that they can fill out a list of questions. It is hoped that from this method, accurate and convincing data are obtained on the problems studied. In this questionnaire method, it is done by distributing questionnaires or questionnaires. The population in this study are consumers who buy motor vehicles in the city of Jambi. The number of samples in this study used the Lemeshow formula, so that the selected sample was 81 respondents

\section{RESULTS AND DISCUSSION}

It is the coefficient of determination $\mathrm{R} 2$ is 0.505 , which means that the contribution of the independent variable is $\mathrm{X} 1$ product quality, $\mathrm{X} 2$ product design affects the $\mathrm{Y}$ variable purchasing decisions by $50.5 \%$ while the remaining $49.5 \%$ is influenced by other variables outside the study. The effect of product quality and design on the decision to purchase a Honda CRV motor vehicle at PT. Sinar Sentosa Jambi (a case study in the city of Jambi) can be seen as follows:

Table 1

Coefficients $^{\mathrm{a}}$

\begin{tabular}{|c|c|c|c|c|c|c|}
\hline \multirow{2}{*}{\multicolumn{2}{|c|}{ Model }} & \multicolumn{2}{|c|}{ Unstandardized Coefficients } & $\begin{array}{l}\text { Standardized } \\
\text { Coefficients }\end{array}$ & \multirow[b]{2}{*}{$\mathrm{T}$} & \multirow[b]{2}{*}{ Sig. } \\
\hline & & $\mathrm{B}$ & Std. Error & Beta & & \\
\hline \multirow[t]{3}{*}{1} & (Constant) & , 472 & ,285 & & 1,653 & , 102 \\
\hline & Product Design & ,184 & ,088 & 222 & 2,100 & ,039 \\
\hline & Product quality & ,611 & , 118 &, 545 & 5,167 & 000 \\
\hline
\end{tabular}

a. Dependent Variable: Buying decision

Based on the table above, it shows that the constant value is 0.472 , meaning that if the independent variable, namely product quality (X1) and product design (X2) is worth (0), then the dependent variable $(\mathrm{Y})$, namely the purchase decision, will have a fixed value of 0.472 . While the regression coefficient of the product quality variable (X1) is 0.611 , meaning that if the product quality variable (X1) has increased by 1 (one) unit while other variables are considered constants, the purchasing decision variable (Y) has increased by 0.472 if the positive variable $\mathrm{X}$ increases and the variable $\mathrm{X}$ increases. $\mathrm{Y}$ increases. Then the regression coefficient of the product design variable (X2) has a positive value of 0.184 , meaning that if the product design 
variable (X2) has increased by 1 (one) unit while the other variables are considered constant, then the variable (Y) of purchasing decisions will increase by 0.472 (if the positive variable is $\mathrm{X}$ increases and $\mathrm{Y}$ variable increases).

Based on the table above, it can be explained that the tcount of the product quality variable (x1) is 2,100 which is greater than 1,66412. $\mathrm{t}$ table significant level of product quality variable $(\mathrm{x} 1)$ is $0.000(<0.05)$. Thus $\mathrm{H} 0$ is rejected and $\mathrm{Ha}$ is accepted. From these results it can be suggested that product quality has a significant effect on purchasing decisions. That the tcount value of product design variable $\mathrm{x} 2$ is 5.167 which is greater than $1.66412 \mathrm{t}$ table of significant level of product design variable $\mathrm{x} 2$ is $0.000(<0.05)$. Thus $\mathrm{H} 0$ is rejected and Ha is accepted. From these results it can be stated that product design has a significant effect on purchasing decisions. Can see the results of the F test below:

Table 2

F Test

\begin{tabular}{|ll|r|r|r|r|r|}
\hline Model & & \multicolumn{1}{|c|}{$\begin{array}{c}\text { Sum of } \\
\text { Squares }\end{array}$} & Df & Mean Square & F & \multicolumn{1}{c|}{ Sig. } \\
\hline 1 & Regression & 9,989 & 2 & 4,995 & 39,838 &, $000^{\mathrm{b}}$ \\
& Residual & 9,779 & 78 &, 125 & & \\
& Total & 19,768 & 80 & & & \\
\hline
\end{tabular}

a. Dependent Variable: Buying decision

b. Predictors: (Constant), Product Quality, Product Design

The results of the table above show that the Fcount value is 39.383 by comparing $\mathrm{F}$ table $=3.11$ with the degree of freedom of the numerator (number of $\mathrm{X}$ ) $=2$ and the degree of denominator (N-K-1) 81, obtained Ftable of 3.11. Fcount is greater than Ftable (39.383>3.11) then $\mathrm{HO}$ is rejected with $\mathrm{Ha}$ accepted, meaning that there is a significant effect between the variables $(\mathrm{X})$ together on the dependent variable (Y). which means it can be said that simultaneously independent product quality and product design affect the dependent variable purchasing decisions.

\section{CONCLUSIONS AND SUGGESTIONS}

\section{Conclusion}

Based on the results of the data analysis research, it can be concluded that the product quality variable with an average score of 343.87 is included in the very high criteria. Product design variables with an average score of 365.73 are included in the very high criteria. Purchasing decisions with an average score of 362.3 are included in the very high criteria. From the results of the coefficient of determination test, it can be seen that product quality and product design have an influence on purchasing decisions for Honda CRV motor vehicles by 50.5\% while the remaining $49.5 \%$ is influenced by other variables.. The correlation value of 0.711 
means that product quality and product design have a very strong relationship between purchasing decisions. Based on the t-test, it is known that the t-count is 5.167 while t-table is 1.66412, which means that product quality and product design have a positive and significant effect on purchasing decisions for Honda CRV motor vehicles. based on the test fcount 39.838 while Ftable 3.11. which means that product quality and product design have a positive and significant effect on purchasing decisions for Honda CRV motor vehicles.

\section{Suggestions}

Based on the results of the Product Quality variable that the lowest score of 354 on the statement that the Honda CRV has sharp angle headlights gives the impression of a fighter motorcycle, in this case it is expected that the company provides manual light mode, because the motor is suitable for extreme roads. From the results of the Product Design variable that the lowest score of 354 on the Honda CRV statement is in accordance with the standards and quality offered, in this case the company is expected to make a new product of the type of supermoto, supermoto is driven on asphalt roads, while trail is driven on extreme roads. If you look at the results of the purchasing decision variables that the lowest score of 340 on the Honda CRV statement has $150 \mathrm{CC}$ according to taste, in this case it is expected to offer products with a higher CC. For further researchers, the results of this study can be used as a comparison and reference for research, and as consideration for further deepening further research with different variables. Other research such as service quality, promotion, brand image, promotion mix, service quality, information quality, service loyalty.

\section{BIBLIOGRAPHY}

Ariella, Irfan R. 2018. Pengaruh Kualitas Produk, Harga Produk da Desain Produk Terhadap Keputusan Pembelian Konsumen Mazelnid. Jurnal Manajemen Volume 3 No 2 Juni 2018.

Azany, F. 2014. Analisis Pengaruh Desain Produk, Motivasi Konsumen dan Citra Merek Terhadap Keputusan Pembelian Sepatu Bellagio.

Ghozali, I, 2016. Aplikasi Analisis Multivariate Dengan Program SPSS 23. Cetakan ke VIII. Penerbit Universitas Diponegoro. Semarang.

Hasibuan, Malayu S.P, 2011. Manajemen Sumber Daya Manusia. Jakarta: PT Bumi Askara.

Khadijah, Susan N dan Khuzaimah, Alimatul. 2017. Pengaruh Kualitas Produk Fitur Produk dan Desain Produk Terhadap Keputusan Pembelian Tas Sophie Pada Business Centre Umi Sutindarwati Gresik. Jurnal Volume Volume 06 Nomor 02 Desember 2017

Kotler, Philip. 2007. Manajemen Pemasaran, Jilid 2. Jakarta : PT.Indeks Kelompok Gramedia.

Kotler, Philip. 2010. Manajemen Pemasaran. Edisi tiga belas Bahasa Indonesia.Jilid 1 dan 2.Jakarta : Erlangga.

Kotler P. \& Amstrong G. 2012. Prinsip-prinsi Pemasaran. Erlangga Jakarta. 
Pahlevi, Anzaruddin, S. 2017. Analisis Pengaruh Persepsi Harga, Promosi, Desain Produk dan Kualitas Produk Terhadap Keputusan Pembelian Sepeda Motor Matic. Jurnal Management Volume 6 No 1 Tahun 2017

Sekaran, Uma . 2011. Metode Penelitian Bisnis. Jakarta. Salemba Empat.

Setiadi, Nugroho J, 2003, Perilaku Konsumen: Konsep dan Implikasi untuk Strategi dan Penelitian Pemasaran. Jakarta : Kencana.

Sugiyono. 2014. Metode penelitian kuantitatif kualitatif dan R\&D. Bandung: Alfabeta.

Sumarwan, Ujang. 2011. Perilaku Konsumen:Teori dan Penerapannya Dalam Pemasaran. Bogor: Ghalia Indonesia

Tjiptono. 2008. Strategi Bisnis Pemasaran. Yogyakarta: Andi.

Tjiptono, F. 2011. Strategi Pemasaran. Yogyakarta: Andi. 